\title{
A STUDY ON ATTRIBUTES INFLUENCING SELECTION OF SHOPPING MALL
}

\section{Dr. Virendra Chavda}

\begin{abstract}
:
Shopping mall preference is being evaluated by using various attributes such as location, tenant mix, mall image and availability of parking. This research explores why retailers prefer to locate in one shopping mall and not another. What attributes makes one shopping mall more desirable to retailers than another? To do so, this research reviews literature for understanding the preference criteria of retail location in the shopping mall context. A descriptive survey of retailers within the mall was carried out through the use of questionnaires as research instruments. The study concludes that with a better understanding of the retailers' mall preference attributes and their site selection criteria and methodologies, shopping mall developers can better understand what attributes, and which information will best help them in improving their mall attractiveness.
\end{abstract}

Key words: Shopping mall, retailers/customers, shopping mall attributes

\subsection{Introduction:}

A shopping mall is a group of retail and other commercial establishments that is planned, developed, owned and managed as a single property, typically with on-site parking provided. The mall's size and orientation are generally determined by the market characteristics of the trade area served by the center. According to the history of shopping mall, the development of shopping malls started in the US and later spread to other countries in the world. Shopping malls first came in to existence in the 1920's in California where supermarkets would anchor and serve as attraction for a strip of smaller stores. India is a late starter in comparison to the western world in the development of shopping malls, but today India is the one of the countries who has the highest amount of shopping malls. Today, shopping malls have 
transformed so much and are in a mature stage of retail life cycle where sales and market share are levelling off. Therefore developers' concerns are now more customer based hence all aspects of a shopping mall should have the need of customers in mind. This study focuses on the understanding the influence of various shopping mall attributes in selection of shopping malls by retailers.

\subsection{Literature Review:}

Preference refers to a greater liking for one alternative over another or others. Preference elements, in the context of this research study, are certain characteristics a retailer wants to have in a shopping mall to make it desirable for him to locate in that mall. Retailers are encountering situations where decisions have to be taken to choose where to locate their businesses. Given the many options of shopping malls available today, decision making on which mall to locate in has become more challenging. When retailers stand between choices of different alternatives they are expected to have some differentiated level of preference concerning the different choice options (Dhar and Simonson 1992). According to classical preference theory, the retailers always have distinct preferences or are using the utility function and thus choose the option that presents the retailer with greatest sales (Dhar and Simonson, 1992). However, preferences are changing rapidly which makes the preferences of today less likely to be the same in the future and is forcing mall developers to continuingly understand preference changes and update their offer to fit retailers and consumers' preferences (Yang, 2002).

Greater agreement among scholars surrounds the importance of proximity in mall preference. Simmons, (1992) emphasizes the importance of proximity by observing that in relation to the location of the shopping mall, proximity is a determinant which is important for shopping at malls. Kaufman, (1996) concurs by stating that time taken to reach the retail outlet is one of the main criteria which the consumers look for while selecting a shopping outlet, which subsequently affect the shops of the mall. Mall image is a multi-dimensional component consisting of both the visible features such as the superiority and availability of goods and services (Chang \& Tu, 2005) and the less tangible features like the atmosphere of the mall (Koo, 2003). According to Gibbs (2012), parking is one of the most critical issues facing any retailer or shopping district today. He observes that, unlike work, school, or obligatory tasks, most shopping trips are elective activities. Levy and Weitz (2012) observed that the importance of good parking facilities must not be overlooked in assessing a location and 
specific sites in a mall while Coombe, (1997) noted that parking affects shopping and travel behaviour of consumers. They noted that parking situation affects shopping destination choice and mode of travel, parking lot choice and route to this parking and frequency of the shopping trip. According to the retailers, a mall which depict good image, accommodates several shops and anchor tenant are considered lucrative business sites (Finn and Louviere, 1996, Konishi and Sandfort, 2003).

\subsection{Research objective:}

- To investigate attributes that influence retailers' preference of selection of shopping malls.

\subsection{Research Methodology:}

- Research Approach \& Nature of Data:

For gathering primary data, survey approach was used

\section{- Research Instrument:}

For this research questionnaire was used. The questionnaire was designed using Likert Scale.

- Sample unit: Retailers/customers of Ahmedabad city

- Sample Size: Total 150 rural respondents of Gandhinagar District

- Sample Procedure: Non probability Convenience Sampling

\subsection{Data Analysis \& findings:}

\subsubsection{Factor Analysis of Shopping Mall Attributes}

The objective of the study, to identify shopping mall attributes in mall selection, was tested by subjecting the ratings of the shopping mall attributes (by respondents) to factor analysis based on the PCA (Principal Component Analysis) method. The respondents were asked to rate the importance of the shopping mall attributes in selecting a shopping mall. The attributes/ variables were measured on a 5-point Likert Scale of importance, with 5 being extremely important and 1 being extremely unimportant.

\subsubsection{Suitability of Factor Analysis (for the Research)}


Kaiser-Meyer-Olkin (KMO) measure of sampling adequacy was used to test the null hypothesis that different shopping mall attributes have different importance as perceived by customers. It is an indicator to scrutinize the suitability of factor analysis.

\section{Table 1: KMO and Bartlett's Test}

\begin{tabular}{|l|l|l|}
\hline Kaiser-Meyer-Olkin Measure of Sampling Adequacy. & .737 \\
Approx. Chi-Square & 7206.258 \\
Bartlett's Test of Sphericity & df & 153 \\
& Sig. & .000 \\
\hline
\end{tabular}

High Values of the KMO score .737 (above 0.5 and upto 1.0); and the Bartlett's test was significant (Chi 7206.258, df $=153$; as per Table 1). This implies that the correlations between pairs of variables can be explained by other variables and that factor analysis was found suitable for this research (Malhotra, 2009; Hair et al., 2006). To determine the method of factor analysis, Principal Components Analysis was used. The purpose was to obtain the minimum possible number of factors, referred as principal components, accounting for maximum variance in the data, for further multivariate analysis. The shopping mall attributes were factor analyzed to produce several factors.

\subsubsection{Results of Principal Components Analysis:}

Communality is the amount of variance shared by a variable with all the other variables being considered. To determine the number of factors, Eigen values approach was used. Here, the factors retained exhibit Eigen values greater than 1.0. These were considered significant as the study also exhibited. Every factor is associated with certain amount of variance referred to as an Eigen value. Therefore, factors included possessed a variance greater than 1.0. Each variable possesses 1.0 variance due to standardization. Hence, the factor exhibiting variance less than 1.0 is as good as a single variable. Further, 17 variables were taken into consideration, as lesser number of variables reveal a traditional number of factors. The percentage of the total variance was attributed to each factor. Rotate Factors - The un rotated or initial factor matrix showed the relationship between the factors and individual variables, 
but the factors were correlated with many variables making these difficult to interpret. Therefore, each variable was rotated using the Varimax Rotation Method with Kaiser Normalization to transform the factor matrix into simple, easily interpretable matrix. Varimax Rotation Method reduced the number of variables with high loadings on preferably one factor making these easier to understand. Rotation converged in 4 iterations.

Table 2: Total Variance Explained

\begin{tabular}{|c|c|c|c|c|c|c|c|c|c|}
\hline \multirow[t]{2}{*}{ Component } & \multicolumn{3}{|c|}{ Initial Eigenvalues } & \multicolumn{3}{|c|}{$\begin{array}{l}\text { Extraction Sums of Squared } \\
\text { Loadings }\end{array}$} & \multicolumn{3}{|c|}{$\begin{array}{l}\text { Rotation Sums of Squared } \\
\text { Loadings }\end{array}$} \\
\hline & Total & $\begin{array}{l}\% \text { of } \\
\text { Variance }\end{array}$ & $\begin{array}{l}\text { Cumulative } \\
\%\end{array}$ & Total & $\begin{array}{l}\% \text { of } \\
\text { Variance }\end{array}$ & $\begin{array}{l}\text { Cumulative } \\
\%\end{array}$ & Total & $\begin{array}{l}\% \text { of } \\
\text { Variance }\end{array}$ & $\begin{array}{l}\text { Cumulative } \\
\%\end{array}$ \\
\hline 1 & 4.867 & 27.036 & 27.036 & 4.867 & 27.036 & 27.036 & 3.054 & 16.965 & 16.965 \\
\hline 2 & 2.963 & 16.462 & 43.499 & 2.963 & 16.462 & 43.499 & 2.898 & 16.103 & 33.068 \\
\hline 3 & 1.715 & 9.529 & 53.027 & 1.715 & 9.529 & 53.027 & 2.738 & 15.209 & 48.277 \\
\hline 4 & 1.380 & 7.665 & 60.692 & 1.380 & 7.665 & 60.692 & 1.940 & 10.775 & 59.052 \\
\hline 5 & 1.251 & 6.949 & 67.642 & 1.251 & 6.949 & 67.642 & 1.546 & 8.589 & 67.642 \\
\hline 6 & .929 & 5.164 & 72.805 & & & & & & \\
\hline 7 & .868 & 4.823 & 77.629 & & & & & & \\
\hline 8 & .710 & 3.946 & 81.575 & & & & & & \\
\hline 9 & .529 & 2.939 & 84.513 & & & & & & \\
\hline 10 & .478 & 2.655 & 87.168 & & & & & & \\
\hline 11 & .446 & 2.480 & 89.649 & & & & & & \\
\hline 12 & .418 & 2.325 & 91.974 & & & & & & \\
\hline 13 & .377 & 2.096 & 94.069 & & & & & & \\
\hline 14 & .305 & 1.695 & 95.765 & & & & & & \\
\hline 15 & .283 & 1.572 & 97.336 & & & & & & \\
\hline
\end{tabular}


\begin{tabular}{|l|l|l|l|l|l|l|l|l|}
16 & .227 & 1.260 & 98.596 & & & & & \\
17 & .180 & .998 & 99.594 & & & & & \\
18 & .073 & .406 & 100.000 & & & & & \\
\hline
\end{tabular}

Extraction Method: Principal Component Analysis.

A factor matrix exhibits factor loadings of all the variables on all the factors extracted. Thus, the variables obtained from review of literature were factor analysed using principal rotated component method to produce five dimension solutions (as shown in Table 3 below).

Table 3 Shopping Mall Attributes Statistics (Customized output from rotated component matrix)

Factors

\section{FACTOR 1: ASSOSRTMENT}

Proper display of Products

Variety/Assortment of brands

Easy availability of Products

Latest Fashion

Warranty of Products

Loyalty Cards

FACTOR 2: STORE QUALITY

Informative Ads

Well assorted Rest areas

Well informed Sales staff

FACTOR 3: CONVENIENCE

Security

0.788

Convenient shopping hours

0.758

Parking
Loading

0.774

0.765

0.679

0.637

0.628

0.61

$\begin{array}{ll}\text { Eigen } & \text { \% of } \\ \text { Value } & \text { Variance } \\ 4.867 & 27.036\end{array}$

4.867

27.036 
Location

FACTOR 4: VALUE FOR MONEY

Exchange facilities

Reasonable Price

Bundling Offers
0.723
7.665

0.745

0.732

0.627

\section{FACTOR 5: STORE - SHOPPER CONNECT}

Price - Quality Equilibrium

Regular Sales Discount
0.815

0.784

From the above table it is seen that Factor 1: Assortment comprises of six attributes having contribution of $27 \%$ in selection of total shopping attributes. It includes following attributes with their factor loadings; proper display of products (0.774), Variety/assortment of brands (0.765), Easy availability of products (0.679), latest fashion (0.637), warranty of products (0.628) and loyalty cards (0.610). Factor 2 : store quality comprises of three attributes having contribution of $16 \%$ in selection of total shopping attributes. It includes following attributes with their factor loadings; informative ads (0.908), well assorted rest areas (0.856) \& well informed sales staff (0.708). Factor 3: convenience comprises of three attributes having contribution of $9 \%$ in selection of total shopping attributes. It includes following attributes with their factor loadings; security (0.788), convenient shopping malls (0.758), parking (0.728) and location (0.723). Factor 4: value for money comprises three attributes having contribution of $7.5 \%$ in selection of total shopping attributes. It includes following attributes with their factor loadings; exchange facility (0.745), reasonable price (0.732) and bundling offers (0.627). Factor 5: store shopper connectivity comprises two attributes having contribution of $7 \%$ in selection of total shopping attributes. It includes following attributes with their factor loadings; price quality equilibrium (0.815) and regular sales discount (0.784).

\subsection{Conclusion:}


From the analysis it is concluded that consumers or retailers prefer those malls in which various types of (Assortment) varieties are available. Whenever difference types of products, prices, schemes and offers are available at the shopping mall retailers are attracted towards that. Story quality and well informed staff also affect the selection of shopping mall. Followed by connectivity, value for money and store and shopper connectivity also affects the selection of various shopping malls.

\subsection{Scope for future research}

Further study can be done in this field for Mall shoppers related to the reputation of malls, offers of the malls and effect of these variables on purchase intention. Also a study can be carried out to identify how these factors create brand loyalty among retailers. 


\subsection{References}

- Chang, C. H. \& Tu, C. Y. (2005). Exploring mall image, customer satisfaction and customer loyalty relationship: evidence form Taiwanese hypermarket industry. The journal of American Academy of Business, 7(2), 197-202.

- Coombe D., Guest P., Bates J. \& Le Masurier P., (1997) Study of parking and traffic demand: 1. The research programme. Traffic Eng. Control 38: 62-67.

- Dhar Ravi, V Simonson, The Effect of Time Pressure on Consumer Choice, Journal of consumer research, Vol 25, March 1999, page 369-372.

- Kaufman, C.F. (1996). A new look at one-stop shopping: A times model approach to matching store hours and shopper schedules. Journal of Consumer Marketing, 13 (1), 4-52.

- Koo (2003). A new look at one-stop shopping: A times model approach to matching store hours and shopper schedules. Journal of Consumer Marketing, 13 (1), 4-52.

- Konishi H. and Sandfort M. T. (2003), “Anchor stores”, Journal of Urban Economies, vol. 53, pp. 413-435.

- Levy M. and Weitz B. A. (2013), "Retail Management”, McGraw Hill, Irwin.

- Levy, M., Weitz, B.A. (2012). Retailing Management. (8th Edition), McGraw Hill, Irwin. Yang, "Customers variety in regional shopping centres: Some UK empirical analyses", Working Paper, University of Reading, Reading, vol. 29, (2004).

\section{Dr. Virendra Chavda}

Head of Department (MBA)

Gandhinagar Institute of Technology (Affiliated with GTU),

At: Moti Bhoyan, Dist: Gandhinagar

(M): 9428411153

E - Mail id: chavdavirendra@gmail.com \& virendra.chavda@git.org.in 